\title{
HUBUNGAN LINGKAR KEPALA BAYI BARU LAHIR DAN KENAIKAN BERAT BADAN IBU SELAMA HAMIL DENGAN KEJADIANRUPTUR PERINEUM DI BPM “Z” BENGKULUTAHUN 2014
}

\section{New Bird Circuit Birth Relationship and Increase Heavy Weight for Pregnancy With Perineum Performance Rupture in BPM "Z" Bengkulu Year 2014}

\author{
Ratna Dewi ${ }^{1}$, Elvi Destariyani ${ }^{1}$ \\ 1 Jurusan Kebidanan Poltekkes Kemenkes Bengkulu \\ Email : elvi destariyani@gmail.com
}

\begin{abstract}
The incidence of ruptur in Indonesia which is only about 5\% of all deliveries in Indonesia. The most important cause of maternal mortality in Indonesia is $40-60 \%$ of bleeding, including bleeding because of the birth canal laceration 4-5\%. Objective of this study was to determine the relationship head circumference of newborns and maternal weight gain during pregnancy with rupture of the perineum in BPM Z.type of research is analytic with case control study design. The population in this study all mothers who gave birth in BPM " $Z$ " in 2013 which amounted to 160 people, with 32 people taken in the case of total sampling and control as many as 32 people and taken by systematic random sampling. Data collected were analyzed by chi-square test. The results showed, obtained 64 respondents, birth mothers with rupturperineum 32 (50\%) occur in mothers who gave birth to the size of head circumference $>34 \mathrm{~cm}$ (71.9\%), and pregnant women who experience weight gain $>12.5$ ( 75.0\%). Results of analysis for head circumference obtained by the P value 0.003 OR 5.622. The results of the analysis of maternal weight gain obtained P 0.003 OR 5.727. This means that there is a significant relationship between head circumference of newborns and maternal weight gain during pregnancy with ruptur of the perineum. Advised pregnant women need to do a routine check of at least four times during pregnancy, in order to be pursued maternal weight gain is within the normal enhancement.
\end{abstract}

Keywords : Head circumference of newborn, maternal weight gain during pregnancy, Ruptur of the perineum

\begin{abstract}
Abstrak
Angka kejadian robekan perineum di Indonesia berkisar 5\% dari seluruh persalinan di Indonesia. Penyebab terpenting kematian maternal di Indonesia adalah perdarahan 40$60 \%$, sebab perdarahan diantaranya laserasi jalan lahir 4-5\%. Jenis penelitian yang digunakan adalah analitik dengan desain penelitian kasus kontrol. Populasi dalam penelitian ini seluruh ibu yang melahirkan di BPM "Z" tahun 2013 yang berjumlah 160 orang, dengan kasus 32 orang diambil secara total sampling dan kontrol sebanyak 32 orang dan diambil secara sistematis random sampling. Hasil pegumpulan data dianalisis dengan uji chi square.

${ }^{1}$ Ratna Dewidan Elvi DestariyaniadalahStafPengajarJurusan Kebidanan Poltekkes Kemenkes Bengkulu
\end{abstract}


Hasil penelitian, diperoleh 64 responden, ibu bersalin dengan ruptur perineum 32 (50\%) terjadi pada ibu yang melahirkan bayi dengan ukuran lingkar kepala $>34 \mathrm{~cm}(71,9 \%)$, dan ibu hamil yang mengalami kenaikan berat badan $>12,5 \quad(75,0 \%)$. Ada hubungan antara lingkar kepala bayi dengana ruptur perineum $(\mathrm{p}=0,003)$ dengan $\mathrm{OR} 5,622$ dan ada hubungan antara kenaikan berat badan ibu hamil dengan ruptur perineum $(P \quad 0,003)$ dengan OR 5,727. Disarankan ibu hamil melakukan pemeriksaan rutin minimal 4 kali saat kehamilan, agar dapat diupayakan kenaikan berat badan ibu berada dalam peningkatan normal.

Kata kunci : Lingkar Kepala, Kenaikan Berat Badan, Ruptur perineum.

\section{PENDAHULUAN}

Ruptur perineum adalah robeknya perineum pada saat janin lahir umumnya terjadi hampir semua persalinan pertama dan tidak jarang juga pada persalinan berikutnya. Robekan dapat terjadi di bagian dalam serviks atau vagina, atau bagian luar genital atau perineum atau anus.[1] Ruptur Perineum dapat terjadi karena adanya ruptur spontan maupun episiotomi perineum yang dilakukan atas indikasi antara lain: bayi besar, perineum kaku, persalinan yang kelainan letak, persalinan dengan menggunakan alat baik forceps maupun vacum. [2]

Kasus ruptur perineum terjadi 2,7 juta pada ibu bersalin di dunia. Angka ini diperkirakan mencapai 6,3 juta pada tahun 2050. Kejadian ruptur perineum di Asia merupakan masalah yang cukup banyak dalam masyarakat, $50 \%$ dari kejadian ruptur perineum di dunia terjadi di Asia. Prevalensi ibu bersalin yang mengalami ruptur perineum di Indonesia pada golongan umur 25-30 tahun yaitu $24 \%$ sedang pada ibu bersalin usia $32-39$ tahun sebesar $62 \%$. [3]

Salah satu penyebab morbiditas dan mortalitas ibu adalah infeksi pada masa nifas dimana infeksi tersebut berawal dari ruptur perineum. Angka Kematian Ibu (AKI) di Indonesia masih cukup tinggi dan jauh berada di atas AKI negara ASEAN lainnya. AKI di Indonesia adalah 359 per 100 ribu kelahiran hidup. Penyebab utama kematian ibu di indonesia tesebut adalah Perdarahan (42\%), Eklampsi/Preeklampsi (13\%), Abortus (11\%), Infeksi (10\%), Partus lama/persalinan macet (9\%) dan Penyebab lain (15\%). [4]

Perdarahan merupakan penyebab utama kematian ibu Penyebab perdarahan utama adalah atonia uteri sedangkan ruptur perineum merupakan penyebab kedua yang hampir terjadi pada setiap persalinan pervaginam. Ruptur perineum dapat mengakibatkan perdarahan, infeksi dan nyeri dalam berhubungan seksual. ${ }^{4}$ Berdasarkan hasil penelitian di beberapa Propinsi di Indonesia didapatkan bahwa satu dari lima ibu bersalin yang mengalami ruptur perineum akan meninggal dunia dengan persentase $21,74 \%$.[5]

Laserasi perineum dipengaruhi oleh beberapa faktor yaitu faktor maternal, faktor janin dan faktor penolong. Faktor maternal meliputi umur ibu, partus presipitatus, mengejan terlalu kuat, perineum yang rapuh dan oedem, paritas, kesempitan panggul dan Chepalo Pelvic Disproposional (CPD), kelenturan vagina, varikosa pada pelvis maupun jaringan parut pada perineum dan vagina, 3 persalinan dengan tindakan seperti ekstraksi vakum, 
ekstraksi forcep, versi ekstraksi dan embriotomi. Faktor janin yang menjadi penyebab kejadian ruptur perineum meliputi kepala janin besar, berat bayi lahir, presentasi defleksi, letak sungsang dengan after coming head, distosia bahu, kelainan kongenital. Faktor penolong meliputi cara memimpin mengejan, cara berkomunikasi dengan ibu, ketrampilan menahan perineum pada saat ekspulsi kepala, anjuran posisi meneran dan episiotomi. [2]

Wanita yang melahirkan bayi besar kadang-kadang menjadi kebanggaan tersendiri bagi seorang ibu atau keluarga tanpa melihat dampak dari proses kelahiran. Trauma pada tulang kepala dan otak janin akibat dari proses persalinan saat melewati jalan lahir merupakan salah satu akibat dari kelahiran bayi yang besar. [2] Sedangkan akibat langsung dari ruptur perineum adalah dapat terjadi perdarahan. Kesalahan dalam menjahit akan menimbulkaninkontinensiaalvi (defekasi tidak dapat ditahan) karena sfingterani tidak terjahit, fistula rektovagina, vagina longgar sehingga akan menjadi keluhan dalam hubungan seksual. [6]

Hasil penelitian Rahmawati (2011) menunjukkan mayoritas ibu bersalin melahirkan bayi dengan berat badan lahir cukup (antara 2500-4000 gram) sebanyak 75 orang $(91,5 \%)$ dan mayoritas ibu bersalin mengalami laserasi derajat I sebanyak 44 orang (53,7 \%). Sedangkan uji statistik Rank Spearman dengan nilai $\rho$ value sebesar 0,016 menunjukkan bahwa Ho ditolak dan Ha diterima, yang berarti ada hubungan secara bermakna antara berat badan lahir dengan derajat ruptur perineum pada persalinan normal. ada hubungan secara bermakna antara berat badan lahir dengan derajat ruptur perineum pada persalinan normal.
Salah satu perubahan yang terlihat jelas pada kehamilan adalah pertambahan berat badan ibu hamil yang disebabkan oleh perkembangan janin dalam kandungan. Suatu pertambahan berat badan yang sesuai dengan umur kehamilan memberikan konstribusi yang besar terhadap kelahiran bayi dengan berat lahir normal (2500 gram sampai 4000 gram).[1] Peningkatan berat badan ibu selamahamil menandakan adanya adaptasi ibu terhadap pertumbuhan janin terdapat penimbunan kelebihan lemak di tubuh yang berlebihan pada ibu hamil. Untuk batas kenormalan kenaikan berat badan ibu hamil sendiri tergantung dari indeks masa tubuh (IMT) wanita sebelum hamil.[2] Hasil penelitian Sunanita (2007) menunjukkan 76,67 \% ibu mengalami kenaikan berat badan $\leq 12,5 \mathrm{~kg}$ dan 13,33\% ibu mengalami kenaikan berat badan $>12,5 \mathrm{~kg}$. Dan menyatakan ada hubungan antara kenaikan berat badan ibu selama hamil dengan berat badan bayi baru lahir.[7]

Survey awal yang dilakukan di 3 BPM di kota Bengkulu menunjukkan, angka kejadian ruptur dari semua persalinan pervaginam terbanyak di BPM "Z" tahun 2011 adalah sebanyak $15,9 \%$ dari 88 persalinan, dan pada tahun 2012 adalah sebanyak 18\% dari 122 persalinan. Tahun 2013 sebanyak 20\% dari 160 persalinan. Hasil survey awal pada tanggal 22-27 februari 2014 didapat 4 dari 7 ibu bersalin spontan pervaginam mengalami ruptur perineum. Berdasarkan data tersebut diatas maka peneliti tertarik untuk meneliti hubungan antara ukuran kepala bayi baru lahir dan kenaikan berat badan ibu selama hamil terhadap kejadian ruptur perineum di BPM "Z" tahun 2014.

Tujuan Mengetahui hubungan antara ukuran lingkar kepala bayi baru lahir dan kenaikan berat badan ibu 
selama hamil terhadap kejadian ruptur perineum di BPM "Z" tahun 2014.

\section{METODE PENELITIAN}

Penelitian ini adalah penelitian analitik dengan pendekatan kasus kontrol. Kelompok kontrol adalah ibu yang tidak mengalami ruptur perineum sedangkan kelompok kasus adalah kelompok ibu bersalin dengan ruptur perineum. Penelitian ini akan menggunakan data sekunder yang diperoleh dari register ibu bersalin, register ibu hamil dan buku KIA responden di BPM "Z" Bengkulu dari bulan Januari sampai Desember 2013.

Populasi dalam penelitian ini adalah semua ibu bersalin di BPM " $Z$ " sebanyak 160 ibu bersalin. Jumlah sampel yang digunakan adalah 64 orang yang terdiri dari 32 kasus (ibu dengan ruptur perineum) dengan menggunakan total sampling, dan 32 kontrol (ibu yang tidak mengalami ruptur perineum) yang diambil secara systematic random sampling atau acak sistematik. Analisis data univariat dan bivariat menggunakan chi-kuadrat.

\section{HASIL DAN PEMBAHASAN}

Tabel 1. Distribusi frekuensi ukuran lingkar kepala BBL, kenaikan BB ibu selama hamil, dan ruptur perineum

\begin{tabular}{lcc}
\hline \multicolumn{1}{c}{ Variabel } & $\mathrm{F}$ & $\%$ \\
\hline Ukuran lingkar kepala & & \\
$>34 \mathrm{~cm}$ & 33 & 51,6 \\
$\leq 34 \mathrm{~cm}$ & 31 & 48,4 \\
Kenaikan BB ibu hamil & & \\
$>12,5 \mathrm{~kg}$ & & \\
$\leq 12,5 \mathrm{~kg}$ & 35 & 54,7 \\
& 29 & 45,3 \\
Ruptur perineum & & \\
Ya & 32 & 50 \\
Tidak & 32 & 50 \\
\hline Jumlah & 64 & $100 \%$ \\
\hline
\end{tabular}

Berdasarkan tabel 1 diketahui lebih dari separuh $(51,6 \%)$ responden memiliki ukuran lingkar kepala bayi $>34 \mathrm{~cm}$, sebagian besar (54,7\%)mengalami kenaikan berat badan lebih dari 12,5 kg selama hamil, dan 32 ibu dari 160 ibu bersalin di Bpm "Z" mengalami ruptur perineum (20\%).

Tabel 2. Analisis hubungan ukuran lingkar kepala bayi BBL terhadap kejadian ruptur perineum

\begin{tabular}{|c|c|c|c|c|c|c|c|c|}
\hline \multirow{3}{*}{$\begin{array}{c}\text { Ukuran Lingkar } \\
\text { Kepala }\end{array}$} & \multicolumn{4}{|c|}{ Ruptur Perineum } & \multirow{2}{*}{\multicolumn{2}{|c|}{ Total }} & \multirow{3}{*}{$\mathrm{p}$} & \multirow{3}{*}{ OR } \\
\hline & \multicolumn{2}{|c|}{ Ruptur } & \multicolumn{2}{|c|}{ Tidak Ruptur } & & & & \\
\hline & $\mathrm{n}$ & $\%$ & $\mathrm{n}$ & $\%$ & $\mathrm{n}$ & $\%$ & & \\
\hline$>34 \mathrm{~cm}$ & 23 & 71,9 & 10 & 31,2 & 33 & 51,6 & & \\
\hline$\leq 34 \mathrm{~cm}$ & 9 & 28,1 & 22 & 68,8 & 31 & 48,6 & 0.003 & $3.0 \angle 2$ \\
\hline
\end{tabular}


Berdasarkan Tabel 2 diketahui dari 32 responden dengan ruptur perineum sebagian besar melahirkan bayi dengan ukuran lingkar kepala bayi $>34 \mathrm{~cm}(71,9 \%)$ mengalami ruptur perineum. Hasil uji statistik chi-square $\mathrm{p}=0,003<0,05$, menunjukkan ada hubungan ukuran lingkar kepala bayi baru lahir dengan ruptur perineum dengan OR 5,62 yang artinya resiko kejadian ruptur perineum 5,62 kali lebih besar pada responden yang melahirkan bayi dengan ukuran lingkar kepala $>34 \mathrm{~cm}$.

Tabel 3. Analisis hubungan kenaikan BB ibu selama hamil terhadap ruptur perineum

\begin{tabular}{|c|c|c|c|c|c|c|c|c|}
\hline \multirow{3}{*}{$\begin{array}{l}\text { Kenaikan BB } \\
\text { ibu hamil } \\
\text { (kg) }\end{array}$} & \multicolumn{4}{|c|}{ Ruptur Perineum } & \multirow{2}{*}{\multicolumn{2}{|c|}{ Total }} & \multirow{3}{*}{$\mathrm{p}$} & \multirow{3}{*}{ OR } \\
\hline & \multicolumn{2}{|c|}{ Ruptur } & \multicolumn{2}{|c|}{ Tidak Ruptur } & & & & \\
\hline & $\mathrm{n}$ & $\%$ & $\mathrm{n}$ & $\%$ & $\mathrm{n}$ & $\%$ & & \\
\hline$>12,5 \mathrm{~kg}$ & 24 & 75 & 11 & 34,4 & 35 & 54,7 & \multirow{2}{*}{0.003} & \multirow{2}{*}{5.727} \\
\hline$\leq 12,5 \mathrm{~kg}$ & 8 & 25 & 21 & 65,6 & 29 & 45,3 & & \\
\hline
\end{tabular}


Berdasarkan tabel 3 diketahui bahwa dari 32 responden dengan ruptur perineum sebagian besar responden mengalami kenaikan berat badan $>12,5$ kg (75\%). Hasil uji statistik chi-square $\mathrm{p}=0,003<0,05$, menunjukkan ada hubungan kenaikan beratbadan ibu selama hamil dengan kejadian ruptur perineum denganOR 5,72 yang artinya resiko kejadian ruptur perineum 5,72 kali lebih besar pada ibu yang mengalami kenaikan berat badan $>12,5 \mathrm{~kg}$ selama hamil. Hasil penelitian menunjukkan bahwa sebagian besar ibu bersalin melahirkan bayi dengan ukuran lingkar kepala bayi lebih dari $34 \mathrm{~cm} \quad(71,9 \%)$ mengalami ruptur perineum, menunjukkan bahwa terdapat hubunganantara ukuran lingkar kepala bayi baru lahir dengan ruptur perineum. Resiko kejadian ruptur perineum 5,62 kali lebih besar pada responden yang melahirkan bayi dengan ukuran lingkar kepala lebih dari $34 \mathrm{~cm}$.Berdasarkan teori yang ada, robekan perineum terjadi pada kelahiran dengan berat lahir yang besar. Hal ini terjadi karena semakin besar bayi yang dilahirkan akan meningkatkan resikoterjadinya ruptur perineum di karenakan berat badan lahir bayi besar berhubungan dengan besarnya janin yang dapat mengakibatkan perineum tidak cukup kuat menahan regangan kepala bayi dengan berat badan lahir yang besar sehingga pada proses kelahiran bayi dengan berat bayi lahir yang besar sering terjadi ruptur perineum.[8] Hasil penelitian ini sejalan dengan teori yang menyatakan bahwa ruptur perineum disebabkan oleh berat lahir bayi yang besar.[9]
Mengendalikan keluarnya kepala bayi secara bertahap dan hati-hati dapat mengurangi regangan berlebihan (robekan) pada vagina dan perineum. Besarnya kepala rata-rata tergantung dari besarnya (berat) janin. Oleh karena itu sebagian ukuran kepala dilihat dari Berat Badan (BB) janin.[10]Hasil penelitian ini sesuai dengan penelitian yang dilakukan oleh Rahmawati (2011) dengan hasil ada hubungan secara bermakna antara berat badan lahir dengan derajat ruptur perineum pada persalinan normal.

Hubungan Kenaikan Berat Badan Ibu Selama Hamil Terhadap Kejadian Ruptur Perineum

Hasil penelitian menunjukkan sebagian besar responden mengalami kenaikan berat badan $>12,5 \mathrm{~kg}$ (75\%). Hasil uji statistik chi-square $\mathrm{p}=0,003<$ 0,05 , menunjukkan ada hubungan kenaikan berat badan ibu selama hamil dengan kejadian ruptur perineum dengan OR 5,72 yang artinya resiko kejadian ruptur perineum 5,72 kali lebih besar pada ibu yang mengalami kenaikan berat badan $>12,5 \mathrm{~kg}$ selama hamil.

Hasil penelitian ini menunjukkan bahwa kenaikan berat badan ibu selama hamil merupakan salah satu penyebab terjadinya ruptur perineum, kenaikan berat badan berlebihan ketika hamil akan menyebabkan ibu melahirkan bayi dengan berat badan berlebih pula, apalagi ketika fakor kenaikan berat badan ibu selama hamil ini didukung oleh faktor lain seperti faktor penolong persalinan maka akan meningkatkan kerentanan terjadinya ruptur perineum. 
Hasil penelitian ini sejalan dengan penelitian yang dilakukan oleh Nurastuti dan Triasih (2013) dengan hasil Hubungan Kenaikan Berat Badan Ibu Selama Hamil Terhadap Kejadian Ruptur Perineum dengan OR (odd ratio) 18,370 (2,189-154,184) berarti bahwa ibu yang mengalami kenaikan berat badan tidak normal $(<12,5$ dan $>17,5 \mathrm{~kg})$ berpeluang 18 kali untuk melahirkan bayi dengan berat badan bayi lahir tidak normal di bandingkan dengan ibu yang kenaikan berat badannya normal $(12,5$ kg-17,5 kg).[11] Hasil ini sesuai dengan teori bahwa Ibu yang kurus dan selama kehamilan disertai penambahan berat badan yang rendah atau turun sampai 10 $\mathrm{kg}$, mempunyai resiko paling tinggi untuk melahirkan bayi dengan BBLR.[2] Sedangkan bayi dengan berat badan lahir besar (>4000gr) maka kemungkinan terjadi ruptur perineum semakin besar karena terjadi kesukaran yang ditimbulkan akibat regangan dinding rahim oleh anak yang sangat besar, dapat timbul inersia uteri dan kemungkinan perdarahan pascapartum akibat atonia uteri dan robekan jalan lahir.[12] Sedang Lingkar Lengan Atas (LLA) adalah antropometri yang dapat menggambarkan keadaan status gizi ibu hamil dan untuk mengetahui resiko Kekurangan Energi Kalori (KEK) atau gizi kurang. Ibu yang memiliki ukuran Lingkar Lengan Atas (LLA) dibawah 23,5 $\mathrm{cm}$ berisiko melahirkan bayi BBLR.[13] Ada juga yang kenaikan berat badan $>17,5 \mathrm{~kg}$ Pertambahan berat badan ibu yang berlebihan selama kehamilan, porsi makanan yang dikonsumsi ibu hamil akan berpengaruh pada berat badan ibu. Asupan gizi yang berlebih bisa mengakibatkan bayi lahir dengan berat di atas rata-rata. Penambahan berat badan hamil yang terlalu tinggi beresiko terhadap komplikasi kehamilan seperti hipertensi, diabetes, dan preeklampsi, komplikasi waktu melahirkan serta makrosomia. Untuk menghindari resikotersebut, ibu hamil harus memperhatikan asupan gizi sebelum, ketika, dan setelah kehamilan ,karena rata-rata penambahan yang di anjurkan di Negara berkembang adalah 12,5 kg.[14]

\section{SIMPULAN DAN SARAN}

Berdasarkan hasil penelitian hubungan lingkar kepala bayi baru lahir dan kenaikan berat badan ibu selama hamil terhadap kejadian ruptur perineum di BPM “Z” Bengkulu Tahun 2014, maka penulis dapat menarik kesimpulan sebagai berikut: ibu bersalindi BPM "Z" yang mengalami ruptur perineum angkanya cukup tinggi yaitu sebanyak 20\% dari 160 persalinan, ibu bersalin di BPM "Z" sebagian besar melahirkan bayi dengan ukuran lingkar kepala bayi baru lahir $>34 \mathrm{~cm}$, ibu bersalin di BPM "Z" sebagian besar mengalami kenaikan berat badan berkisar $>12,5 \mathrm{~kg}$ selama hamil, ada hubungan antara ukuran lingkar kepala bayi baru lahir terhadap kejadian rupur perineum dengan $\mathrm{OR}$ 5,622 dan ada hubungan antara kenaikan berat badan ibu selama hamil terhadap kejadian ruptur perineum dengan $\mathrm{OR}$ 5,727 .

Diharapkan pada tenaga kesehatan khususnya bidan, asisten bidan dan mahasiswa magang di BPM "Z" dapat memberikan penyuluhan tentang faktor predisposisi yang dapat menyebabkan ruptur perineum seperti ukuran lingkar kepala bayi baru lahir dan kenaikan berat badan yang berlebihan selama hamil dan pencegahan ruptur perineum. 


\section{DAFTAR RUJUKAN}

[1] Sarwono. Ilmu Kebidanan, edisi 3, jakarta : Yayasan Bina Pustaka Sarwono Prawirohardjo. 2007

[2] Cunningham, G. Obstetri Williams. Jakarta : EGC. 2005

[3] Rahmawati. Hubungan berat badan lahir dengan derajat rutur perineum pada persalinan normal di RSIA Kumala Siwi Pencangaan Jepara. Jurnal Kesehatan dan Budaya Volume 04 No 01 Edisi Juni 2011

[4] SDKI. Angka Kematian Ibu. Jakarta: Survei Demografi dan Kesehatan Indonesia; 2012.

[5] Nugroho. Kasus Emergency Kebidanan. Yogyakarta : Nuha Medika .2010

[6] Manuaba,IBG. Pengantar kuliah obstetri.Jakarta : EGC. 2010.

[7] Sunanita. Hubungan kenaikan berat badan ibu hamil dengan berat badan bayi baru lahir. STIKES NU Tuban.2007

[14] Sulistyawati, Ari. Asuhan Kebidanan pada Masa Nifas. 2009
[8] Sekartini, 2007. Penatalaksanaan Bayi Baru Lahir dan Pencegahan Komplikasi. Dikutip dari : www. mediaindonesia.co.id. Diakses pada Februari 2010

[9] Varney, Buku Ajaran Asuhan Kebidanan Vol.2.Jakarta : E;GC. 2008

[10] Varney, 2008.Buku Ajaran Asuhan Kebidanan Vol.2.Jakarta : E;GC

[11] Nurastuti dan Triasih (2013) Hubungan Kenaikan Berat Badan Ibu Selama Hamil Terhadap Kejadian Ruptur Perineum. EJurnal Obstetrika Volume 1 No 2 Tahun 2013

[12] Sastrawinata, Sulaiman. Dkk. Ilmu Kesehatan Reproduksi Obstetri Patologi, edisi II. Jakarta: EGC. 2004

[13] Departemen Kesehatan RI. Asuhan Persalinan Normal. Jakarta: JNPKKR. 